\title{
The Economics of Social Capital and Health
}

A Conceptual and Empirical Roadmap 
World Scientific Series in Global Healthcare Economics and Public Policy

ISSN: 2010-2089

Series Editor-in-Chief: Richard M Scheffler

University of California, Berkeley, USA

\section{Published:}

Vol. 1 Accountability and Responsibility in Health Care:

Issues in Addressing an Emerging Global Challenge

edited by Bruce Rosen, Avi Israeli and Stephen Shortell

Vol. 2 The Economics of Social Capital and Health:

A Conceptual and Empirical Roadmap

edited by Sherman Folland and Lorenzo Rocco 
World Scientific Series in Global Healthcare Economics and Public Policy - Vol. 2

\title{
The Economics of Social Capital and Health
}

A Conceptual and Empirical Roadmap

\author{
Edited by \\ Sherman Folland \\ Oakland University, USA \\ Lorenzo Rocco \\ University of Padova, Italy \\ Foreword by \\ Richard M. Scheffler \\ University of California, Berkeley
}




\section{Published by}

World Scientific Publishing Co. Pte. Ltd.

5 Toh Tuck Link, Singapore 596224

USA office: 27 Warren Street, Suite 401-402, Hackensack, NJ 07601

UK office: 57 Shelton Street, Covent Garden, London WC2H 9HE

\section{Library of Congress Cataloging-in-Publication Data}

Folland, Sherman, author.

The economics of social capital and health : a conceptual and empirical roadmap /

Sherman Folland and Lorenzo Rocco.

p. ; cm. -- (World Scientific series in global healthcare economics and public policy ; volume 2)

Includes bibliographical references and index.

ISBN 978-9814293396 (hardcover : alk. paper)

I. Rocco, Lorenzo, 1975- author. II. Title. III. Series: World Scientific series in global healthcare economics and public policy ; v. 2. 2010-2089

[DNLM: 1. Public Health--economics. 2. Community Networks--economics. 3. Health

Promotion--economics. 4. Social Networking. WA 30]

RA410.5

$362.1--\mathrm{dc} 23$

2013041078

\section{British Library Cataloguing-in-Publication Data}

A catalogue record for this book is available from the British Library.

Copyright (C) 2014 by World Scientific Publishing Co. Pte. Ltd.

All rights reserved. This book, or parts thereof, may not be reproduced in any form or by any means, electronic or mechanical, including photocopying, recording or any information storage and retrieval system now known or to be invented, without written permission from the publisher.

For photocopying of material in this volume, please pay a copying fee through the Copyright Clearance Center, Inc., 222 Rosewood Drive, Danvers, MA 01923, USA. In this case permission to photocopy is not required from the publisher.

In-house Editor: Chye Shu Wen

Typeset by Stallion Press

Email: enquiries@stallionpress.com 
This volume has been an excellent opportunity for the building of social capital, and is dedicated to the many people who contributed in many ways to its creation. 
This page intentionally left blank 


\section{Foreword}

This book contains cutting-edge theoretical and empirical thinking on the relationship between social capital and health. The distinctive feature of this book is that its contributions are made by economists whose points of view differ from those of others who have contributed to this literature. The book seeks to address six questions, the answers to which are unique contributions to understanding the relationship between social capital and health:

1. What do economists working in the health arena bring to the intellectual debate on social capital that others have not?

2. What do economists have to offer to the understanding of the possible links and relationships between social capital and health?

3. Which paradigms in economics are the most useful in understanding the possible links and relationships between social capital and health?

4. What have economists studied empirically? What are the weaknesses of these studies?

5. How do economists attempt to overcome the weaknesses in their empirical work?

6. What factors contribute to the social capital and health relationship?

This book begins by laying out the theoretical foundations between social capital and health. Chapters 1-5 focus on the theoretical and conceptual issues, while Chapters 6-10 focus on the empirical and policy relationships between social capital and health. Readers will think differently and more deeply about the relationship between social capital and health after reading this book.

Richard M. Scheffler

Distinguished Professor of Health Economics University of California, Berkeley January 2014 
This page intentionally left blank 


\title{
About the Contributors
}

\begin{abstract}
Sherman Folland attained a Ph.D in Health Economics at the University of Iowa in 1975. He is presently Professor at Oakland University in Michigan. He and his wife, Donna, have two cherished daughters now in their twenties. Folland has published over 30 articles in Health Economics; Journal of Health Economics; Health Economics, Policy and Law; Social Science \& Medicine and others. His earlier work covering a variety of topics proved useful for his contributions to the successful, co-authored textbook The Economics of Health and Health Care. For the past 10 years, he has researched solely on questions in the economics of social capital and health, especially working on causality issues and efforts to improve the theory.
\end{abstract}

Lorenzo Rocco attained a Ph.D in economics at the University of Toulouse I, France, in 2005 before moving back to Italy where he is currently Assistant Professor of Economics at the University of Padova. He is an empirical economist and his fields of research include the socio-economic determinants of health, the influence of health on the labor market outcomes and several aspects of the economics of education. His research has been published in The Economic Journal, Health Economics, Public Choice among others. He has also contributed to several reports commissioned by the World Bank, World Health Organization and The European Commission.

Eline Aas is Associate Professor in Health Economics at the Department of Health Management and Health Economics at the University of Oslo, and has an honorary contract with the University of York. Aas' research is related to inequalities in health, social capital on health, estimation of health care costs and economic evaluation.

José Anchorena attained a Ph.D in Economics, Carnegie Mellon University. His main interests are economic development, macroeconomics, public policy and economic history. He has been visiting researcher at University of Oslo and is presently Director of Economic Development at Fundación Pensar, Argentina. 
Yumna Bahgat attained a B.A. in Social Welfare with a minor in Global Poverty and Practice at the University of California, Berkeley. She is a researcher at the Nicholas C. Petris Center of Health Care Markets and Consumer Research and has worked on the Berkeley Forum Report project.

Beatrice d'Hombres works at the Joint Research Center of the European Commission (Unit of Econometrics and Applied Statistics). She has been with the Joint Research Center since 2006 and she holds a Ph.D in Economics from the University of Clermont-Ferrand, France. Her research interests are in education and health economics as well as in applied econometrics.

Elena Fumagalli holds a Ph.D in Economics from the University of Venice and she is now a post-doctorate at the University of Lausanne. She has worked at the University of East Anglia and she has been consultant for the European Commission. She is interested in economics of aging, risky behaviors, social capital/social networks and the evaluation of public policies.

Kamrul Islam is a senior researcher at Uni Rokkan Centre in Bergen, Norway. He obtained his Ph.D in Health Economics from Lund University, Sweden in 2007, and MSc in Health Economics from the University of York, in 2000. Dr. Islam has extensive experience with cross-disciplinary research and he has published his research in reputed international journals.

Tor Iversen is Professor of Health Economics at the University of Oslo, Norway. His research interests include social capital and health, the role of economic incentives in health care and comparative health system research.

Oddvar Kaarbøe is Professor of Economics at the University of Bergen. He is also the research director of Health Economics Bergen (HEB). His main research area is the financing of health care institutions.

Audrey Laporte is an Associate Professor of Health Economics at the Institute for Health Policy, Management and Evaluation at the University of Toronto. Her work in the area of social capital has looked at the various ways that it can influence both health outcomes at a population level and health, and health care utilization at the individual level.

Sachiko Ozawa is an Assistant Scientist at Johns Hopkins Bloomberg School of Public Health in the Department of International Health. She applies health economic methods to improve health systems in low- and middle-income countries. 
Her current research focuses on vaccines, health insurance, and the role of trust/social capital in health care.

Lucas Ronconi is a development economist working at the Centro de Investigación y Acción Social (CIAS) in Argentina. He received a Ph.D from the University of California Berkeley, a Fulbright scholarship, and a medal from the Global Development Network (GDN). His research has been published in several journals including Economics Letters, Health Economics, and Industrial Relations.

Richard M. Scheffler is Distinguished Professor of Health Economics and Public Policy at the School of Public Health and the Goldman School of Public Policy at the University of California, Berkeley. He also holds the Chair in Health Care Markets \& Consumer Welfare endowed by the Office of the Attorney General for the State of California. Professor Scheffler is Director of The Nicholas C. Petris Center on Health Care Markets and Consumer Welfare. Professor Scheffler has published over 150 papers and edited and written six books. He has conducted a recent review on Pay For Performance in Health for the World Health Organization and the OECD. He is also Vice Chair of the Berkeley Forum for Improving California's Healthcare Delivery System and the lead author of the Berkeley Forum Report. 
This page intentionally left blank 


\section{Contents}

Foreword $\quad$ vii

About the Contributors $\quad$ ix

Chapter 1. Introduction to the Economics of Social Capital and Health

Sherman Folland and Lorenzo Rocco

Chapter 2. What is Social Capital and How Does It Work to Improve Health?

Sherman Folland

Chapter 3. How Do We Invest in Social Capital? An Exploration of an Economic Model of Social Capital and Health

Sherman Folland, Oddvar Kaarbøe

and Kamrul Islam

Chapter 4. Social Capital: An Economic Perspective

Audrey Laporte

Chapter 5. How Does Social Capital Arise in Populations?

Sherman Folland and Tor Iversen

Chapter 6. Measures of Social Capital

Richard M. Scheffler and Yumna Bahgat

Chapter 7. The Empirics of Social Capital and Health

Lorenzo Rocco and Elena Fumagalli 
Chapter 8. Social Capital and Health in Low- and Middle-Income Countries

José Anchorena, Lucas Ronconi and Sachiko Ozawa

Chapter 9. Social Capital and Smoking

Lorenzo Rocco and Beatrice d'Hombres

Chapter 10. Policy Implications

Eline Aas

Index 